\title{
The impact of radiofrequency electromagnetic radiation from mobile phone on oestrous cycle and reproductive hormones in female wistar rats (Rattus norvegicus)
}

\author{
*Olarinoye, A.O. ${ }^{1}$, Oyewopo, A.O. ${ }^{2}$, Olarinoye, J.K. ${ }^{3}$, Olagbaye, B.A. ${ }^{2}$
}

\begin{abstract}
Aim of Study: The study was aimed at evaluating the impact of radiofrequency electromagnetic radiation (RF-EMR) from mobile phones on the oestrous cycle and reproductive hormones in female Wistar rats.
\end{abstract}

Methods: Twenty-one Mature female Wistar rats weighing 180 to 250 gramswere acclimatized for 2 weeks and divided into control (A), $4 \mathrm{hrs}$ (B) and $6 \mathrm{hrs}$ (C) groups and were exposed to RE-EMF for a period of 28 days. Oestrous cycle was monitored daily and hormonal level was determined using standardized enzymatic colorimetric methods. One-way analysis of variance was used to compare the mean values of variables among the groups accepting statistical significance at $\mathrm{p} \leq 0.05$.

Results: Oestrous cycle was deranged in experimental group compared to the control. Mean serum level of Follicle stimulating hormone (FSH) in control group remained low compared to the exposed groups. Luteinizing hormone (LH) levels in group A were almost double that of the group B and C, while the serum level of Oestrogen was lowest in group A. Progesterone level in the control group was higher than the experimental group

Conclusion: RF EMR showed an adverse effect on the weight and oestrous cycle but the effect on the reproductive hormones is not significant although the effect appeared to be related to the duration of exposure.

Keyword: Radiofrequency electromagnetic radiation, Oestrous cycle, Reproductive hormones

*Corresponding Author,

Olarinoye, A.O.

ORCID-NO: http://orcid.org/0000-0002-9784-0596

Email: olarinoye.ao@unilorin.edu.ng

\footnotetext{
${ }^{1}$ Department of Obstetrics and Gynaecology, University of Ilorin, Ilorin, Nigeria

${ }^{2}$ Department of Anatomy, University of Ilorin, Ilorin, Nigeria

${ }^{3}$ Department of Internal Medicine, University of Ilorin, Ilorin, Nigeria
} 


\title{
L'impact du rayonnement électromagnétique radiofréquence du téléphone portable sur le cycle oestral et les hormones de reproduction chez les rats femelles wistar (Rattus norvegicus)
}

\author{
*Olarinoye, A.O. ${ }^{1}$, Oyewopo, A.O. ${ }^{2}$, Olarinoye, J.K. ${ }^{3}$, Olagbaye, B.A. ${ }^{2}$
}

\section{Resume}

Objectif de l'étude: L'étude visait à évaluer l'impact du rayonnement électromagnétique radiofréquence (RF-EMR) des téléphones portables sur le cycle œstral et les hormones de reproduction chez les rats Wistar femelles.

Méthode: Vingt et un rats Wistar femelles matures pesant de 180 à 250 grammes ont été acclimatés pendant 2 semaines et divisés en groupes de contrôle (A), 4 heures $(\mathrm{B})$ et 6 heures $(\mathrm{C})$ et ont été exposés à RE-EMF pendant une période de 28 jours . Le cycle œstral a été surveillé quotidiennement et le niveau hormonal a été déterminé en utilisant des méthodes colorimétriques enzymatiques standardisées. Une analyse de variance à un facteur a été utilisée pour comparer les valeurs moyennes des variables parmi les groupes acceptant une signification statistique à $\mathrm{p} \leq 0,05$.

Resultats: Le cycle stral était dérangé dans le groupe expérimental par rapport au témoin. Le taux sérique moyen d'hormone folliculostimulante (FSH) dans le groupe témoin est resté faible par rapport aux groupes exposés. Les taux d'hormone lutéinisante (LH) dans le groupe A étaient presque le double de ceux des groupes $\mathrm{B}$ et $\mathrm{C}$, tandis que le taux sérique d'œstrogène était le plus bas dans le groupe $\mathrm{A}$. Le taux de progestérone dans le groupe témoin était plus élevé que dans le groupe expérimental.

Conclusion: L'emr rf a montré un effet indésirable sur le poids et le cycle œstral mais l'effet sur les hormones de reproduction n'est pas significatif bien que l'effet semble lié à la durée d'exposition.

Mot clé: Rayonnement électromagnétique radiofréquence, Cycle œstral, Hormones de la reproduction

*Corresponding Author,

Olarinoye, A.O.

ORCID-NO: http://orcid.org/0000-0002-9784-0596

Email: olarinoye.ao@unilorin.edu.ng

\footnotetext{
${ }^{1}$ Department of Obstetrics and Gynaecology, University of Ilorin, Ilorin, Nigeria

${ }^{2}$ Department of Anatomy, University of Ilorin, Ilorin, Nigeria

${ }^{3}$ Department of Internal Medicine, University of Ilorin, Ilorin, Nigeria
} 


\section{INTRODUCTION}

Electromagnetic radiations are energy carrying waves created by oscillations of electric and magnetic fields (1). Humans have never been exposed to as wide range of electromagnetic field (EMF) in history like they are today. Cell phones currently account for the largest source of EMF exposure with subscribers now over 5.9 billion worldwide $(2,3)$. Analogue Nordic Mobile Telephone (NMT) was introduced in the 80 s and operated at an electromagnetic resonance of 902.5MHz. Around a decade later, the global system of mobile communications (GSM) succeeded the NMT, operating at a radiofrequency electromagnetic radiation (RFEMR) of $902.4 \mathrm{MHz}$, pulsing at $217 \mathrm{~Hz}$. Today, we have a recent digital cellular system (DCS) operating at a radiofrequency electromagnetic radiation (RF-EMR) of $1800 \mathrm{MHz}$ (1). This shows that advancement in cellular telecommunication system is often accompanied with increasing electromagnetic signal.

However, in vivo and in vitro studies had indicated that EMF exposure can alter cellular homeostasis, activate voltage-gated calcium channels, affect brain functions, endocrine function, reproductive functions and foetal growth in animals (4-7). A study on pregnant rats and their offspring exposed to $900 \mathrm{MHz}$, $1800 \mathrm{Mhz}$ and $2450 \mathrm{MHz}$ reported a high lipid peroxidation levels in both mother and offspring (8). Electromagnetic radiation (EMR) induced toxicity observed at the cellular level include free radicals and $\mathrm{Ca}^{2+}$ mediated cell growth inhibition, DNA damage and protein misfolding (7).

Several studies have investigated the effect of EMF on male reproductive system (5,6,9-13), while some authors believe that electromagnetic radiations from mobile phones do not impact the deep organs in the body since the tissues closest to the phone absorbs more energy (14), these studies have proven that prolonged exposure to radiofrequency as low as $900 \mathrm{MHz}$ from mobile phones can trigger dangerous oxidative stress and alter serum follicle stimulating hormone (FSH), luteinizing hormone ( $\mathrm{LH})$, activin $\mathrm{B}$ and inhibin $B$ in male rats (13).

However, the extent of impact RF-EMR emitted from cellular phone have on female reproductive cycle is still poorly researched. Data obtained from both animal and human studies have shown adverse effects on granulosa cell numbers of ovarian follicles, endometrial tissue, oocyte and embryoquality $(4,15,16)$. Researchers have also suggested that EMF exposure may disturb normal folliculogenesis (17). The aim of this study is to evaluate the impact of radiofrequency electromagnetic radiation from mobile phones on the oestrous cycle and reproductive hormones of Wistar rats.

\section{MATERIALS AND METHODS Ethical Approval}

The investigation was conducted in accordance with the National Institutes of Health Guide for the Care and Use of Laboratory Animals and was approved by University Ethical Review Committee (UERC) of University of Ilorin with approval no: UERC/ASN/2020/2030, and every effort was made to minimize both the number of animals used and their suffering.

\section{Study Design}

This experiment was conducted at the Department of Anatomy, Faculty of Basic Medical Sciences, University of Ilorin, Ilorin, Nigeria. Twenty-one Mature female white Wistar rats (Rattusnorvergicus) weighing 180 to 250 grams were housed in plastic containers measuring about $80 \mathrm{~cm}$ by $50 \mathrm{~cm}$ with wire mesh tops and maintained in well ventilated room at $25^{\circ} \mathrm{c} \pm 2^{\circ} \mathrm{c}$. They were fed liberally on standard rat chow and water and were allowed to acclimatize for 2 weeks. The rats were divided into 3 groups (A, B and C) of 7 rats per group. Each group was housed in 4 or 3 rats per cage, such that each group had 2 cages for the 7 rats. Group A served as the control group and were not exposed to cell phones radiofrequency wave. Group B were exposed to the radiofrequency waves from cell phone for 4 hours daily for 28 days, while group C were exposed for 6 hours daily for 28 days. Each rat was labelled for easy identification while their daily weights were recorded. Vaginal smears of the rats were also examined every morning to determine if the rats had progressive oestrous cycle, this was commenced immediately after acclimatization throughout the entire period of study.

\section{Protocol for exposure to Cell Phone's RF-EMF}

Partner mobile 2G GSM, PF1 model, Dual SIM 1.77-inch screen emitting slightly above $900 \mathrm{MHz}$ were used for this study. Complete ringing duration of the phones were determined to be 45 seconds for a full call, so in order to achieve a 4hour ringing, 320 calls were made into group B phone and 480 calls into group C phone to achieve 6 hours complete polyphonic ringing per day,i.e., for Group B: $4 \times 60 \times 60=14400$ seconds $/ 45$ seconds $=320$ calls; while for Group C: $6 \times 60 \times 60=21600$ 
seconds $/ 45$ seconds $=480$ calls. Group B were exposed for 4 hours and Group C for 6 hours every day for 28days, while the phones placed in the control group was switched off and their cages were kept in a different room from the experimental groups.

\section{Determination of Oestrous Cycle}

Each rat was gently lifted by the tail to expose the vagina to get a smear. The tip of a plastic pipette filled with $10 \mu \mathrm{L}$ of normal saline $(\mathrm{NaCl} 0.9 \%)$ was squirted gently into each rat's vagina. Vaginal fluid was then aspirated with the same pipette and placed on labelled glass slides. Unstained secretions were observed under a light microscope for three types of cells (epithelial, cornified and leukocytes). The proportion of these cells was used to determine the phase of the oestrous cycle for the rats.

\section{Sample Preparation}

At the end of the exposure, the rats were anaesthetized with Phenobarbital sodium at a dose of $50 \mathrm{mg} / \mathrm{kg}$ intraperitoneal immediately after determining each rat's oestrous phase. Animals were immobilized by cervical fracture. Blood was collected through cardiac puncture into sample bottles and the blood was centrifuged at $5000 \mathrm{rpm}$ for $15 \mathrm{~min}$ to obtain the serum. Serum was stored frozen until it was sent for biochemical assay.

\section{Hormonal Analysis}

Follicle stimulating hormone (FSH), Luteinizing hormone (LH) and Oestrogen and Progesterone were measured by standardized enzymatic colorimetric methods using assay kit obtained from Randox Laboratory Ltd. (Co. Antrim, UK).

\section{Statistical analysis}

Data were expressed as means \pm SEM. Statistical group analysis was performed with Statistical Package for Social Sciences. SPSS version 21.0 software. One-way analysis of variance (ANOVA) was used to compare the mean values of variables among the groups. Statistically significant differences were accepted at $P \leq 0.05$.

\section{RESULT}

\section{Effect of cell phone RF-EMR on the body weight of specimens}

A graphical representation of the changes in the weights of the rats during the period of study is shown in Figure 1. The rats showed an initial increase in weight in the first 3 weeks of the study, the weight gain was initially gradual then became more rapid, the rate of weight gain was always greater in the control group. The control group(A) continued to gain weight steadily till the end of the study, rats in the most exposed group (C) began to lose weight, while rats in group B exhibited erratic weight changes with an initial sharp decrease followed again by an equally sharp increase and then a very gradual decrease.

\section{Effect of cell phone RF-EMR on the Oestrous cycle}

The oestrous cycles of rats in the control and experimental group were shown in figures 2 and 3. The rats exposed to zero radiation maintained a cyclical pattern of proestrus, oestrus, metestrus and dioestrus phases, while those of the rats exposed to 4 and 6 hours of radiation were deranged. The derangement was worse in rats exposed to 6 hours of radiation than rats which had 4 hours of RF-EMR exposure.

\section{Effect of cell phone RF-EMR on serum levels of the Hormones}

Serum levels of both the pituitary and the ovarian hormones were shown in Table 1. Mean serum level of FSH in group A (control) 6.81土 6.67remained low while levels in the two experimental groups B $33.2 \pm 20.49$ and C,35.78 \pm 24.18 were much higher, although the difference was not statistically significant. LH levels in the control $51.51 \pm 4.08$ were almost double that of group B 51.51 \pm 4.08 and C29.72 \pm 22.9 , while the serum level of Oestrogen was low in group A (329.74 \pm 313.13$)$ and higher in group B 535.62 \pm 218.52 and group C 535.62 \pm 218.52 . Progesterone level in the control group417.510 \pm 6.25 was higher than the experimental group B (307.94 \pm 253.27 and $C(264.215 \pm 54.39)$ but the difference was not significant.

\section{DISCUSSION}

Effects of radiofrequency electromagnetic radiation emitted from mobile phones on the female reproductive system are still being studied. Existing results from previous studies have shown some significant toxicity in male rats $(5,6,11,18)$. This study has provided evidences of possible pathological effect of mobile phone RF-EMR as low as $900 \mathrm{MHz}$ on the menstrual system of rats.

Our result showed an irregular weight loss pattern in the animals exposed to RF-EMR but no significant difference among the study 
groups. Weight gain increased shortly at onset of the study but began to reduce gradually in rats exposed to 4hours while the eventual decline was more observable in rats exposed to 6 hours of daily exposure. The weight of Rats in the control group (A) plateaued between $3^{\text {rd }}$ to $4^{\text {th }}$ week and then began to rise again. This finding seems to negate the reports of Nisbet et al (19) and Fahmy et al (20) which showed weight gain of up to $71 \%$ in the exposed group of Wistar rats as compared to $34 \%$ weight gain in the control. While some showed loss of weight in the exposed group ${ }^{(21)}$ and no appreciable difference between the experimental group and control (22). This loss in weight could be as a result of reduced food and fluids consumption and dehydration from thermal effects of the radiation. This is similar to the report of Tsuji et al. (23) that food consumption in electromagnetic exposed animals was lower than in unexposed animals.

The oestrous cycle among the rats in the control group not exposed to RF EMR remained cyclical and regular, however that of the 4 hour exposed rats showed irregularities with while the irregularies appeared worse with the more exposed rats in group c. The cycles were also prolonged from the 4 days cycle to about 5 days in group c rats. This was similar to studies by

Asghari et al (24) and Gye et al (25) which indicated that EMF radiations elongated the oestrous cycle in exposed rats, this would eventually lead to reduction in ovulation and reduction in fertility rate. Gyeet al also noted that this effect depended on the frequency, duration and strength of the radiation (25).

The gonadotropins and gonadal hormones showed changes in their mean levels and this is similar to what was obtained in some other studies. These changes although marked were not statistically significant. The study revealed markedly raised levels of FSH in group $\mathrm{B}$ and $\mathrm{C}$ when compared to the control group (A), there is a correspondingly high oestrogen level in these 2 groups as compared to the control group. Showing a hypergonadotropic i.e., "hypergonadic"state. This suggests an abnormality of the HPO axis. The negative feedback to the rising oestrogen level is not reflected. There was a low LH and correspondingly low level of progesterone in groups $\mathrm{B}$ and $\mathrm{C}$ which also suggests anovulation. The rising oestrogen was expected to cause an $\mathrm{LH}$ surge which would lead to ovulation which can often be determined by the raised progesterone level but this positive feedback also appeared to have been affected. This may be caused by a modulatory effect of the radiation on oestrogen receptor or insensitivity of the receptors. The radiation probably affected the oestrogen receptors such that $\mathrm{LH}$ response to rising levels to initiate a surge which would lead to ovulation did not occur. Similarly, the inhibitory response to FSH from the rising oestrogen was also possibly affected. Other similar studies have shown varying results in the ovarian and Pituitary hormones. Mikolajczyk (26) found an increase in LH but no change in FSH levels in rats exposed to $2.8 \mathrm{GHz}$ RF-EMR at $100 \mathrm{~W} / \mathrm{m}$ for $6 \mathrm{~h}$ a day, 6 days a week, for 6 weeks (27). Gye and Park also showed no significant difference in levels of the gonadotropins in female rats (25). The study of the effect of short wave EMR on rats also indicated abnormality in the gonadal hormone resulting in decreased mating and reduced pregnancy rates among the exposed rats (28). Studies in male Wistar rats showed a reduction in the levels of FSH, LH, and testosterone with increasing duration of exposure of the rates (5).

\section{CONCLUSION}

RF EMR had an adverse effect on the weight, oestrous cycle and a minor distortion on the reproductive hormones of the exposed Wistar rats in this study. The effect on the hormones though not significant, appeared to be related to the duration of exposure. It is however envisaged that if the exposure of RF-EMR is sustained beyond 6 weeks, it will likely lead to a reduction in fertility and fecundity of the rats.

Source of Funding: Research was fully funded by the authors.

Conflict of Interest: Authors have no conflict of interest to declare

\section{REFERENCES}

1. Roelandts R. Cellular phones and the skin. Dermatology. 2003 Jul 10;207(1):3.

2. Kaszuba-Zwoińska J, Gremba J, Gałdzińska-Calik B, Wójcik-Piotrowicz K, Thor PJ. Electromagnetic field induced biological effects in humans. PrzegladLekarski. 2015 Jan 1;72(11):636-41.

3. Sieroń-Stołtny K, Teister Ł, Cieślar G, Sieroń D, Śliwinski Z, Kucharzewski M, Sieroń A. The influence of electromagnetic radiation generated by a mobile phone on the skeletal system of rats. BioMed research international. 2015 Feb 1;2015.

4. Merhi ZO. Challenging cell phone impact on reproduction: a review. Journal of assisted reproduction and genetics. 2012 Apr 1;29(4):2937.

5. Oyewopo AO, Olaniyi SK, Oyewopo CI, Jimoh AT. Radiofrequency electromagnetic radiation 
from cell phone causes defective testicular function in male Wistar rats. Andrologia. 2017 Dec;49(10):e12772.

6. Oyewopo AO, Olaniyi SK, Oyewopo CI, Jimoh AT. Cell phone alters oxidative status and impairs testicular function of male wistar rats. J. Reprod. Endocrinol. Infertil. 2017;2(1):22.

7. Altun G, Deniz ÖG, Yurt KK, Davis D, Kaplan S. Effects of mobile phone exposure on metabolomics in the male and female reproductive systems. Environmental research. 2018 Nov 1;167:700-7

8. Yüksel M, Nazıroğlu M, Özkaya MO. Long-term exposure to electromagnetic radiation from mobile phones and Wi-Fi devices decreases plasma prolactin, progesterone, and estrogen levels but increases uterine oxidative stress in pregnant rats and their offspring. Endocrine. 2016 May 1;52(2):352-62.

9. Gul A, Çelebi H, Uğraş S. The effects of microwave emitted by cellular phones on ovarian follicles in rats. Archives of Gynecology and Obstetrics. 2009 Nov 1;280(5):729-33.

10. Odac1 E, Özyılmaz C. Exposure to a $900 \mathrm{MHz}$ electromagnetic field for 1 hour a day over 30 days does change the histopathology and biochemistry of the rat testis. International journal of radiation biology. 2015 Jul 3;91(7):547-54.

11. Okechukwu CE. Effects of mobile phone radiation and exercise on testicular function in male Wistar rats. Nigerian Journal of Experimental and Clinical Biosciences. 2018 Jul 1;6(2):51.

12. Sepehrimanesh M, Davis DL. Proteomic impacts of electromagnetic fields on the male reproductive system. Comparative Clinical Pathology. 2017 Mar 1;26(2):309-13.

13. Sepehrimanesh M, Saeb M, Nazifi S, Kazemipour $\mathrm{N}$, Jelodar G, Saeb S. Impact of $900 \mathrm{MHz}$ electromagnetic field exposure on main male reproductive hormone levels: a Rattusnorvegicus model. International journal of biometeorology. 2014 Sep 1;58(7):1657-63.

14. deSeze R, Fabbro-Peray P, Miro L. GSM radiocellular telephones do not disturb the secretion of antepituitary hormones in humans. Bioelectromagnetics: Journal of the Bioelectromagnetics Society, The Society for Physical Regulation in Biology and Medicine, The European Bioelectromagnetics Association. 1998;19(5):271-8.

15. Batellier F, Couty I, Picard D, Brillard JP. Effects of exposing chicken eggs to a cell phone in "call" position over the entire incubation period. Theriogenology. 2008 Apr 1;69(6):737-45.

16. Diem E, Schwarz C, Adlkofer F, Jahn O, Rüdiger H. Non-thermal DNA breakage by mobile-phone radiation $(1800 \mathrm{MHz})$ in human fibroblasts and in transformed GFSH-R17 rat granulosa cells in vitro. Mutation Research/Genetic Toxicology and Environmental Mutagenesis. 2005 Jun 6;583(2):178-83

17. Roshangar L, Hamdi BA, Khaki AA, Rad JS, Soleimani-Rad S. Effect of low-frequency electromagnetic field exposure on oocyte differentiation and follicular development. Advanced biomedical research. 2014;3.

18. Nazıroğlu M, Yüksel M, Köse SA, Özkaya MO. Recent reports of Wi-Fi and mobile phone-induced radiation on oxidative stress and reproductive signaling pathways in females and males. The Journal of membrane biology. 2013 Dec 1;246(12):869-75.

19. Nisbet HO, Akar A, Nisbet C, Gulbahar MY, Ozak A, Yardimci C, Comlekci S. Effects of electromagnetic field $(1.8 / 0.9 \mathrm{GHz})$ exposure on growth plate in growing rats. Research in Veterinary Science. 2016 Feb 1;104:24-9.

20. Fahmy HM, Mohammed FF, Abdelrahman RT, Abu Elfetoh MM, Mohammed YA. Effect of radiofrequency waves emitted from conventional WIFI devices on some oxidative stress parameters in rat kidney. J Drug MetabToxicol. 2015;6(195):2.

21. Aziz IA, EL-KhozondarHJ, Shabat M, ElwasifeK, Mohamed-Osman A. Effect of electromagnetic field on body weight and blood indices in albino rats and the therapeutic action of vitamin $\mathrm{C}$ or $\mathrm{E}$. Education. 1995 May; 1999.

22. Smialowicz RJ, Weil CM, Kinn JB, Elder JA. Exposure of rats to $425-\mathrm{MHz}(\mathrm{CW})$ radiofrequency radiation: Effects on lymphocytes. Journal of Microwave Power. 1982 Jan 1;17(3):211-21.

23. Tsuji Y, Nakagawa M, Suzuki Y. Five-tesla static magnetic fields suppress food and water consumption and weight gain in mice. Industrial health. 1996;34(4):347-57.

24. Asghari A, Khaki AA, Rajabzadeh A, Khaki A. A review on Electromagnetic fields (EMFs) and the reproductive system. Electronic physician. 2016 Jul;8(7):2655.

25. Gye MC, Park CJ. Effect of electromagnetic field exposure on the reproductive system. Clinical and experimental reproductive medicine. 2012 Mar;39(1):1.

26. Mikolajczyk H. 1978. Biological effects of electromagnetic fields below $300 \mathrm{MHz}$ (pregnancy, litter size and gonadotropic activity of the anterior pituitary gland). Med Pr 29: 111-120.

27. Black DR, Heynick LN. Radiofrequency (RF) effects on blood cells, cardiac, endocrine, and immunological functions. Bioelectromagnetics. 2003;24(S6):S187-95.

28. Yu C, Peng RY. Biological effects and mechanisms of shortwave radiation: a review. Military Medical Research. 2017 Dec;4(1):1-6.

How to cite this article:

Olarinoye, A.O., Oyewopo, A.O., Olarinoye, J.K., Olagbaye, B.A. The impact of radiofrequency electromagnetic radiation from mobile phone on oestrous cycle and reproductive hormones in female wistar rats (Rattus norvegicus). Research Journal of Health Sciences, 2021,9(3): 282-288 


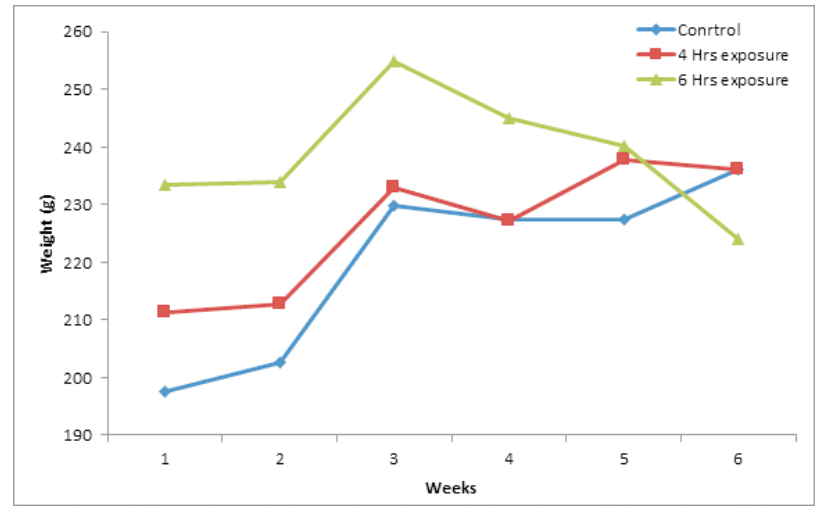

Figure 1.Weight changes in study animals throughout the period of study

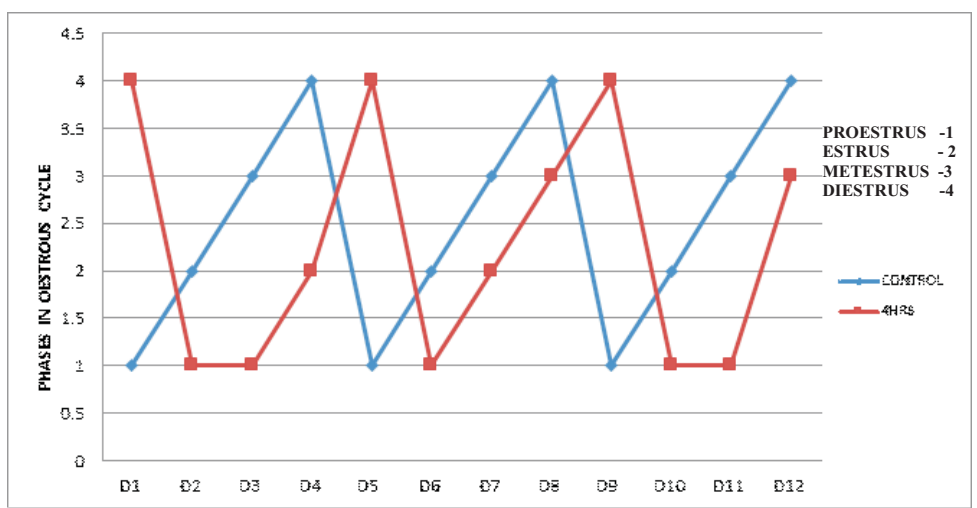

Figure2. Pattern of oestrous cycle in control and rats exposed to $4 \mathrm{hrs}$ of radiation

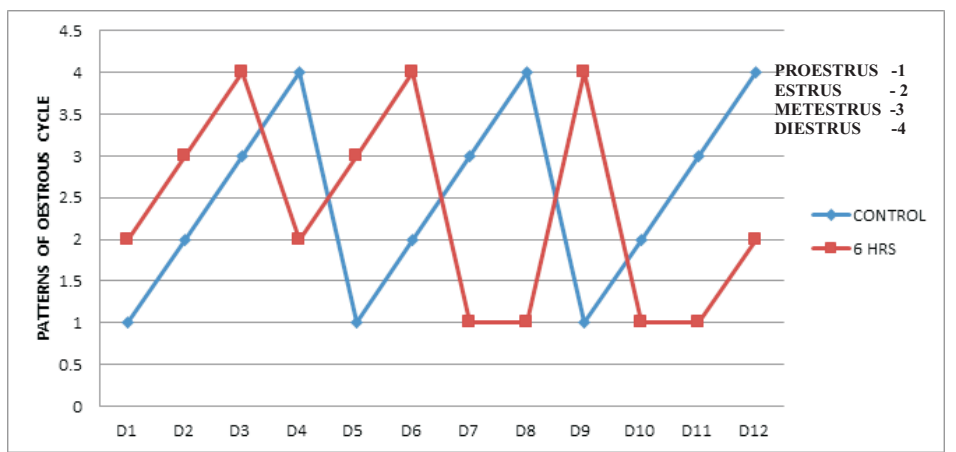

Figure 3. Pattern of oestrous cycle in control and rats exposed to $6 \mathrm{hrs}$ of radiation

Table 1: Showing Mean Serum levels of Ovarian and Pituitary Hormones

\begin{tabular}{llll}
\hline Hormones & Group & $\begin{array}{l}\text { Mean serum levels } \\
(\mathbf{n g} / \mathbf{m l})\end{array}$ & $\boldsymbol{P}$ value \\
\hline FSH & Group A & $6.81 \pm 6.67$ & 0.20 \\
& Group B & $33.2 \pm 20.49$ & \\
LH & Group C & $35.78 \pm 24.18$ & \\
& Group A & $51.51 \pm 4.08$ & 0.31 \\
& Group B & $29.54 \pm 12.64$ & \\
Oestrogen & Group C & $29.72 \pm 22.9$ & \\
& Group A & $329.74 \pm 313.13$ & 0.56 \\
\multirow{2}{*}{ Progesterone } & Group B & $535.62 \pm 218.52$ & \\
& Group C & $535.62 \pm 218.52$ & \\
& Group A & $417.510 \pm 6.25$ & 0.06 \\
& Group B & $307.94 \pm 253.27$ & \\
\hline
\end{tabular}

